\title{
Linking bacterivory and phyletic diversity of protists with a marker gene survey and experimental feeding with BrdU-labeled bacteria
}

\author{
Scott A. Fay ${ }^{1,3}$, Rebecca J. Gast ${ }^{2}$, Robert W. Sanders ${ }^{1, *}$ \\ ${ }^{1}$ Temple University, Biology Department, Philadelphia, Pennsylvania 19122, USA \\ ${ }^{2}$ Woods Hole Oceanographic Institution, Woods Hole, Massachusetts 02543, USA \\ ${ }^{3}$ Present address: Berkeley Initiative in Global Change Biology, University of California, Berkeley, California 94720, USA
}

\begin{abstract}
Over the last few decades, molecular methods have vastly improved our ability to study the diversity of microbial communities. In molecular diversity surveys, the function of protists is often inferred from phylogeny. Yet these surveys are unable to distinguish between different trophic modes among closely related taxa. Here we present results from a culture-independent study linking bacterivory to the diversity of pelagic protists from 3 depths of a stratified mesotrophic lake. Bacteria were labeled with bromodeoxyuridine (BrdU) and added to lakewater samples; after incubation, total DNA was extracted from filtered samples. Part of the DNA extract was subjected to immunoprecipitation with anti-BrdU antibodies, and then both whole DNA and BrdU-labeled samples were analyzed using 454-pyrosequencing of the v9 region of 18S small subunit rRNA gene amplicons. The results show that a different community of protists exists at each depth, with limited overlap of taxonomic composition between depths. The community of BrdU-labeled protists, deemed putative bacterivores, is largely a subset of the community found in the whole DNA samples. Many of these BrdU-labeled taxa are poorly represented in GenBank and thus are probably rarely isolated and/or uncultured species. Several of the taxa identified as bacterivores are also phototrophs, highlighting the important role of mixotrophy among eukaryotic microbes. Definitive identity of functional traits among taxa requires careful experimentation, yet this method allows a first-pass assay of the trophic role of microbial eukaryotes from environmental samples.
\end{abstract}

KEY WORDS: Molecular methods - Microbial community · Mixotrophy · Bromodeoxyuridine · Culture-independent $\cdot$ Eukaryotic microbes $\cdot$ Pyrosequencing $\cdot$ Lake microbes

Resale or republication not permitted without written consent of the publisher

\section{INTRODUCTION}

Microorganisms are crucial to the function of all ecosystems and biogeochemical cycles. In aquatic ecosystems, microbes typically make up the majority of biomass, carbon fixation, and nutrient cycling (Azam et al. 1983). Due to their extremely diverse metabolic pathways, prokaryotic microbes are major contributors to many of these biogeochemical processes (Newman \& Banfield 2002). Eukaryotic microbes (protists) also play major roles in decomposition, nutrient recy- cling, and ecosystem energy flow, including carbon fixation (Paul 2007). Bacterivorous protists remineralize nutrients otherwise tied up in bacterial biomass, are the link between prokaryotic microbes and higher trophic levels, and are a major factor in regulating bacterial population size and community structure in aquatic ecosystems (Sherr \& Sherr 2002).

The use of molecular tools in microbial ecology has bloomed over the last $25 \mathrm{yr}$, allowing the discovery of diversity, taxonomic affinity, and ecology of many unculturable or morphologically indistinct prokary- 
otes and protists (Olsen et al. 1986). Pyrosequencing has further improved our ability to rapidly characterize whole microbial communities and identify rare lineages (Sogin et al. 2006). Increasingly these marker gene surveys, such as amplicon pyrosequencing of a community's rRNA genes, have been applied to examine eukaryotic microbial communities (Stoeck et al. 2010, Bik et al. 2012). Although amplicon pyrosequencing has limited utility in determining relative abundance between species because of gene copy number variation and non-linear PCR amplification (Medinger et al. 2010), next-generation amplicon sequencing is effective for rapidly analyzing microbial taxon richness and community structure from environmental samples. However, the ability of marker gene surveys to discern the function of a particular microbial taxon typically depends only on the taxon's phylogenetic affinity with well-studied organisms, i.e. those in culture.

Culture-independent methods such as stable isotope probing can be combined with marker gene surveys to more directly infer the function of recovered taxa (Gutierrez-Zamora \& Manefield 2010). Another related method uses bromodeoxyuridine (BrdU), a thymidine analog commonly applied in molecular and cell biology studies of cell proliferation, which becomes incorporated as a cell undergoes DNA synthesis. In microbial ecology, BrdU has been used to identify metabolically active microbes and determine phylotype-specific growth rates from environmental samples (Urbach et al. 1999). In these methods, BrdU is added to environmental samples, where the compound is taken up by active microbes and incorporated into their DNA. By immunoprecipitation (IP), BrdU-labeled DNA is separated from a subsample of the whole DNA extract, preparing for further analysis by standard molecular ecology techniques. This method has also been used to study bacterivory: organisms that ingest bacteria labeled with BrdU themselves become labeled (Randa 2007).

We coupled the ability to trace the transfer of BrdU-labeled bacterial DNA into bacterivores (Randa 2007 ) with environmental marker gene survey pyrosequencing to investigate protistan bacterivore diversity at 3 distinct depth layers (epilimnion, metalimnion, and hypolimnion) in a thermally stratified lake. We compared these data with overall microbial eukaryote diversity at the same depths. The communities of bacterivorous protists were less diverse, but largely overlapped with the whole community of protists in the thermally stratified lake, with the greatest diversity of both groups in the mid-depth metalimnion.

\section{MATERIALS AND METHODS}

\section{Preparation of BrdU-labeled bacteria}

Cultures of Pasteurella sp. (isolated from Ice House Pond, Massachusetts, USA, size 0.6-0.7 × $1.2 \mu \mathrm{m}$ ) and Planococcus sp. (isolated from Barnegat Bay, New Jersey, USA, diameter $\leq 1 \mu \mathrm{m}$ ) were maintained in $1 \%$ yeast extract (YE) solution and $0.1 \%$ YE solution in 32 psu artificial sea water, respectively (Kemp et al. 1993). For BrdU-labeling experiments, $5 \mathrm{ml}$ of YE supplemented with $20 \mu \mathrm{M}$ 5-bromo-2'-deoxyuridine (BrdU, Sigma B5002) were inoculated with bacteria and incubated for $36 \mathrm{~h}$ at room temperature (RT) in the dark. BrdU-labeled bacterial stocks were enumerated using epifluorescence microscopy from samples collected onto black $0.2 \mu \mathrm{m}$ polycarbonate filters (Millipore GTBP02500) and stained with DAPIVectashield (Vector Labs H-1200). BrdU-labeled Planococcus sp. bacteria were used for assessment of IP efficiency as described below. The BrdU-labeled Pasteurella sp. were prepared for environmental lakewater experiments and were harvested by centrifugation $(3000 \times g, 10 \mathrm{~min})$, washed 3 times, and dispersed and resuspended by pipetting with cold phosphate-buffered saline.

\section{DNA extraction}

A hot detergent, bead homogenization protocol adapted by Gast et al. (2004) from Kuske et al. (1998) was used for all DNA extractions. Bacterial cultures were harvested by centrifugation, and DNA was directly extracted from cell pellets. Organisms in environmental samples and the field experiment were collected by vacuum filtration on $47 \mathrm{~mm}$ polycarbonate $0.8 \mu \mathrm{m}$ (Millipore ATTP04700) filters.

\section{Dot blots to determine positive labeling of bacteria}

Before use, bacterial strains were tested to verify incorporation of BrdU using dot blots in a protocol adapted from Ueda et al. (2005). For each sample, $10 \mu \mathrm{l}$ of $25 \mathrm{ng}^{\mathrm{l}} \mathrm{l}^{-1}$ genomic DNA was denatured by incubation with $40 \mu \mathrm{l}$ of $0.4 \mathrm{~N} \mathrm{NaOH}$ for $30 \mathrm{~min}$ at RT. Samples were then placed on ice to prevent annealing and neutralized with $50 \mu \mathrm{l}$ cold $2 \mathrm{M}$ ammonium acetate. Using a microfiltration device (Bio-Rad 1706545), samples were dot-blotted onto nitrocellulose membrane pre-wetted with $6 \times$ saline sodium citrate buffer (SSC, $0.9 \mathrm{M} \mathrm{NaCl}, 90 \mathrm{mM}$ sodium citrate, $\mathrm{pH}$ 
7.0). Each well was then rinsed once with $2 \times \mathrm{SSC}$, the membrane was removed, rinsed again with $2 \times \mathrm{SSC}$, and baked at $80^{\circ} \mathrm{C}$ under vacuum for $2 \mathrm{~h}$. After blocking for 30 min at RT with $1 \%$ dry nonfat milk in TBS$\mathrm{T}$ (50 mM Tris, $150 \mathrm{mM} \mathrm{NaCl}, 0.05 \%$ Tween 20, pH 7.6), membranes were probed by adding monoclonal anti-BrdU mouse IgG (Sigma B-8434) at a 1:5000 dilution, washed $3 \times 10 \mathrm{~min}$ with TBS-T, incubated $1 \mathrm{~h}$ with anti-mouse HRP-conjugated IgG (Cell Signaling 7076), and then washed $3 \times 20$ min with TBST. Blots were visualized with ECL Plus (Pierce 32132) and X-OMAT LS film (Kodak 868-9358).

\section{Immunoprecipitation}

IP of BrdU-labeled bacterial DNA was performed following the protocol published by Urbach et al. (1999). One modification was the use of unlabeled bacterial genomic DNA from Pasteurella sp. (instead of eukaryotic salmon sperm DNA, as used in the Urbach protocol, Urbach et al. 1999) in the blocking step. This was to prevent contamination of the samples with exogenous eukaryotic (salmon) DNA that would subsequently amplify with eukaryotic ribosomal gene primers.

\section{qPCR assessment of IP efficiency}

SYBR-based quantitative PCR (qPCR) was used to assess the efficiency of the IP protocol. DNA extracts from Planococcus sp., labeled and unlabeled with BrdU, underwent IP as above. Primer3 (Rozen \& Skaletsky 2000) was used to design quantitative PCR primers for the 16S rRNA gene of Planococcus bacteria, Plano16SqPCRf, 5'-GTG TGT AGC CCA GGT CAT AAG G-3' and Plano16SqPCRr, 5'-GAT CTT AGT TGC CAG CAT TCA GT-3'. Unknown sample and standard curve (using purified genomic Planococcus DNA) reactions were done in triplicate.

\section{qPCR assessment of uptake of BrdU by protists from bacteria}

Cultures of the bacterivorous protist Paraphysomonas sp. (Macaluso et al. 2009) were fed BrdUlabeled Pasteurella bacteria over a time course to examine incorporation of BrdU into the protist DNA. Uptake was determined by qPCR of Paraphysomonas DNA after immunoprecipitating whole DNA extracts from samples after 0, 6, 12, and 24 h. Para- physomonas-specific primers were designed as above (Paraphyso_18S_qF: 5'-GCC TGC GGC TTA ATT TGA CT-3', and Paraphyso_18S_qR: 5'-CAA CTA AGA ACG GCC ATG CA-3'), and reactions were done in triplicate.

\section{Field site and bacterial feeding}

Our field site was Lake Lacawac $\left(41^{\circ} 22.912^{\prime} \mathrm{N}\right.$, $\left.75^{\circ} 17.543^{\prime} \mathrm{W}\right)$ in the Pocono Mountains, Pennsylvania, USA. Lacawac is a $13000 \mathrm{yr}$ old glacial lake formed by ice scour with a maximum depth of $13 \mathrm{~m}$, with surface chlorophyll ranging from 2 to $5 \mathrm{Mg} \mathrm{l}^{-1}$. This 21 ha mesotrophic lake and its watershed remain undeveloped and are protected by the Lacawac Sanctuary Foundation. The annual phytoplankton community in Lake Lacawac is dominated by chrysophycean algae (Siver \& Chock 1986), at times including known mixotrophs (bacterivorous algae) like the colonial flagellates Dinobryon and Uroglena. Small mixotrophic flagellated nanophytoplankton are the dominant bacterivores in the lake during winter (Berninger et al. 1992), and occur in the lake during other seasons (R.W. Sanders pers. obs.).

On 1 October 2010, the water column oxygen and temperature profiles in the lake were characterized using a dissolved oxygen-temperature meter (YSI Model 85) to identify the depths of the mixed surface layer (epilimnion), the thermocline (metalimnion), and the deeper, cool hypolimnion (Fig. 1). Near dusk,

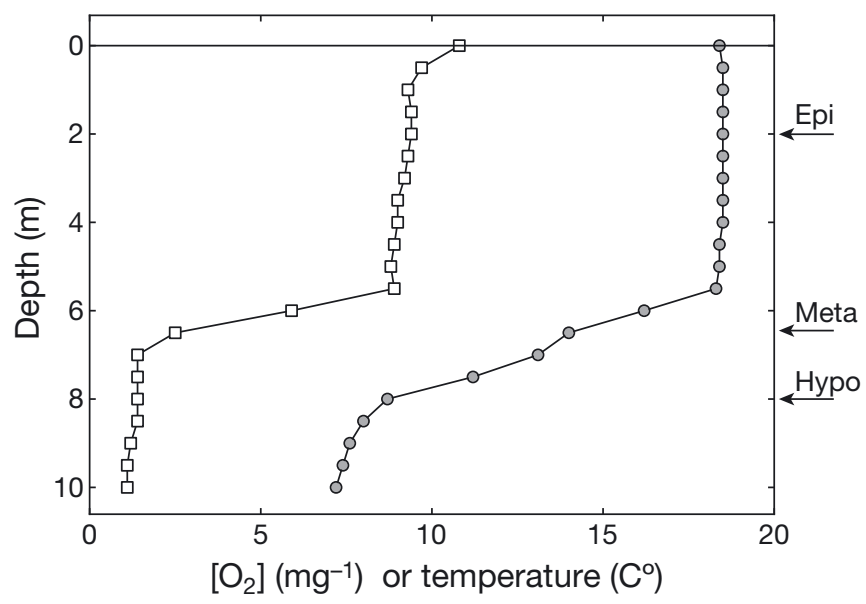

Fig. 1. Depth profile of Lake Lacawac (Pennsylvania, USA) taken on 1 October 2010, indicating thermal and chemical $\left(\mathrm{O}_{2}\right)$ stratification. Open squares represent dissolved oxygen $\left(\mathrm{mg} \mathrm{l}^{-1}\right)$, and circles represent water temperature $\left({ }^{\circ} \mathrm{C}\right)$. Three sampling depths are indicated: Epi: epilimnion, Meta: metalimnion, Hypo: hypolimnion 
samples were taken from these distinct layers of the thermally stratified water column using a Van Dorn bottle, and were gently prefiltered through a $250 \mu \mathrm{m}$ Nitex mesh into incubation flasks to remove the larger crustaceans that prey on the protist community. BrdU-labeled bacteria at a final concentration of $1 \times 10^{6}$ cells ml $^{-1}$ ( $30 \%$ of the typical native bacterial abundance) were added to the $500 \mathrm{ml}$ samples, and the closed flasks were immediately returned to their respective sampled depths attached to a moored rope and incubated overnight and into the morning for a total of $16 \mathrm{~h}$. Light levels were determined just prior to sample retrieval with a Li-Cor LI-250A light meter and LI-193 spherical quantum sensor; the light extinction coefficient $(\eta)$ was $0.73 \mathrm{~m}^{-1}$. Recovered flasks were kept on ice in the dark until filtered, within $2 \mathrm{~h}$ of recovery.

From each incubation flask, $250 \mathrm{ml}$ were filtered onto a $0.8 \mu \mathrm{m}$ polycarbonate filter, DNA was isolated, and a $2 \mu \mathrm{g}$ subsample of DNA from each whole DNA sample was used for BrdU-IP as described above. Thus 6 DNA samples were obtained for downstream analyses: 'whole DNA' (i.e. not treated by BrdU-IP) and 'BrdU-IP' from each of the 3 depths: epilimnion, metalimnion, and hypolimnion (Fig. 1).

\section{Denaturing gel gradient electrophoresis (DGGE)}

Before proceeding with the pyrosequencing run, DGGE was used to examine how the BrdU-IP community profiles compared to those from the whole DNA sample. Protocol was followed as published by Gast et al. (2004).

\section{Primers, PCR amplicon preparation, and pyrosequencing}

We incorporated forward PCR primer 1391F (Stoeck et al. 2010) and reverse primer 1510R (Amaral-Zettler et al. 2009) into fusion primers with Lib-L 1-way read sequencing adaptors and keys as described by 454 Life Sciences Corp. (2010). Forward Primer A 1391F incorporated 6 unique $10 \mathrm{bp}$ Multiplex IDs (MIDs) to distinguish the 6 different amplicon libraries. We chose these primers because, among all of the possible pairs of small subunit (SSU) rRNA V9 region eukaryotic universal primers reported by AmaralZettler et al. (2009) and Stoeck et al. (2010), this pair, 1391F (5'-CCA TCT CAT CCC TGC GTG TCT CCG AC-TCA G-[MID]-GTA CAC ACC GCC CGT C-3') and 1510R (5'-CCT ATC CCC TGT GTG CCT TGG
CAG TC-TCA G-CCT TCY GCA GGT TCA CCT AC- $\left.3^{\prime}\right)$, has the greatest coverage against a UCLUST $70 \%$ clustered subset (consisting of 3164 centroids) of the SILVA eukaryotic SSU rRNA database.

For each sample, we performed 3 PCR reactions, each at a volume of $50 \mu \mathrm{l}$ that contained $0.2 \mu \mathrm{M}$ of each primer, $1 \times$ reaction buffer, $200 \mu \mathrm{M}$ each dNTP, and 0.5U Phusion DNA Polymerase (New England Biolabs F-553). Cycling conditions were as follows: $98^{\circ} \mathrm{C}$ for $120 \mathrm{~s} ; 10$ cycles of $98^{\circ} \mathrm{C}$ for $15 \mathrm{~s}, 67^{\circ} \mathrm{C}$ decremented by $1^{\circ} \mathrm{C}$ cycle $^{-1}$ for $20 \mathrm{~s}$, and $72^{\circ} \mathrm{C}$ for $15 \mathrm{~s} ; 25$ cycles of $98^{\circ} \mathrm{C}$ for $15 \mathrm{~s}, 57^{\circ} \mathrm{C}$ for $20 \mathrm{~s}$, and $72^{\circ} \mathrm{C}$ for $15 \mathrm{~s}$; and a final extension step of $72^{\circ} \mathrm{C}$ for $120 \mathrm{~s}$. Each sample was purified with AMPure XP beads (Beckman Coulter A63880) following the manufacturer's protocol. The University of Pennsylvania DNA Sequencing Facility performed the sequencing reaction using a '1-way read' approach to amplicon pyrosequencing with the GS Junior Titanium emPCR Lib-L kit, as recommended by 454 Life Sciences (2010). The resulting read data and our associated analytical results were deposited in the National Center for Biotechnology Information (NCBI) Sequence Read Archive (SRA) under accession number SRA048528.

\section{Pyrosequencing marker gene survey data analysis}

We removed barcodes, primers, and low-quality sequences and de-multiplexed the data using QIIME (Caporaso et al. 2010). Sequences were de-noised using the algorithm of Reeder \& Knight (2010) implemented in QIIME. Chimeras were removed by de novo detection using UCHIME, and operational taxonomic units (OTUs) were clustered at $95 \%$ identity using UCLUST, both implemented in USEARCH (Edgar 2010). It is critical to implement an analytical pipeline that filters out pseudodiversity, especially from PCR chimeras (Behnke et al. 2011). A second de novo check for chimeras was performed after the final list of OTUs was established. Many of the chimeras may have been removed earlier in the process of clustering the OTUs at $95 \%$ identity and removing taxa that did not identify as 'eukaryote' against the Ribosomal Database Project (RDP) database. Linux bash shell scripts were written when necessary to prepare data for different applications. QIIME was used to generate rarefaction plots, and OTU tables were exported to PRIMER 6 (Clarke \& Warwick 2001) for analysis of community similarity using a variety of metrics. To incorporate phylogenetic signal in our analyses, we used UniFrac 
(Lozupone et al. 2007) implemented in QIIME. OTUs were assigned as putative bacterivores if $>70 \%$ of the total sequence reads for a given OTU were found in the BrdU-IP treatments; only those OTUs with $>0.05 \%$ sequence read abundance, i.e. $>38$ reads total, were considered.

\section{RESULTS AND DISCUSSION}

\section{Effectiveness of labeling and precipitation}

Not all strains of bacteria will take up and incorporate thymidine or its analog BrdU into DNA (Hamasaki et al. 2007). Consequently, it is important to test experimental bacteria to ensure that sufficient labeling will occur. Anti-BrdU dot blots demonstrated that DNA of both Pasteurella and Planococcus was effectively labeled when grown in media supplemented with BrdU.

Quantitative PCR was used to verify that IP effectively isolated BrdU-labeled DNA. IP of BrdU-labeled DNA from Planococcus bacteria yielded $13.0 \pm 0.7 \mathrm{ng}$ $\mathrm{\mu l}^{-1}$ (95\% CI) of Planococcus DNA, while IP of unlabeled control DNA from Planococcus bacteria yielded only $53 \pm 6.6 \mathrm{pg} \mathrm{pl}^{-1}$ (95\% CI) This represents a 245 fold enrichment of labeled over unlabeled DNA. The time course of a bacterivorous protist, Paraphysomonas, feeding on BrdU-labeled bacteria demonstrated that these protists take up BrdU from their food (Fig. 2). In laboratory experiments, Randa (2007) also found that a marine strain of Paraphysomonas and a marine ciliate, Uronema sp., ingested BrdUlabeled bacteria and incorporated the label into their genomic DNA in laboratory experiments.

Analysis of the DGGE gels showed that the BrdUIP samples in our field experiment had fewer total bands than the whole DNA samples. This was expected since the putative bacterivores (BrdUlabeled taxa, BrdU-IP) should be a subset of the whole community of microbial eukaryotes (whole DNA untreated with IP). While some of the DGGE bands appearing in the BrdU-IP samples were unique, most were shared with the whole DNA samples. In these instances of shared band presence, the BrdU-IP bands were often brighter, suggesting greater representation in that recovered DNA pool.

\section{Diversity of protists}

After initial quality filtering, which removed $12.6 \%$ of sequences, clustering OTUs at $95 \%$ identity

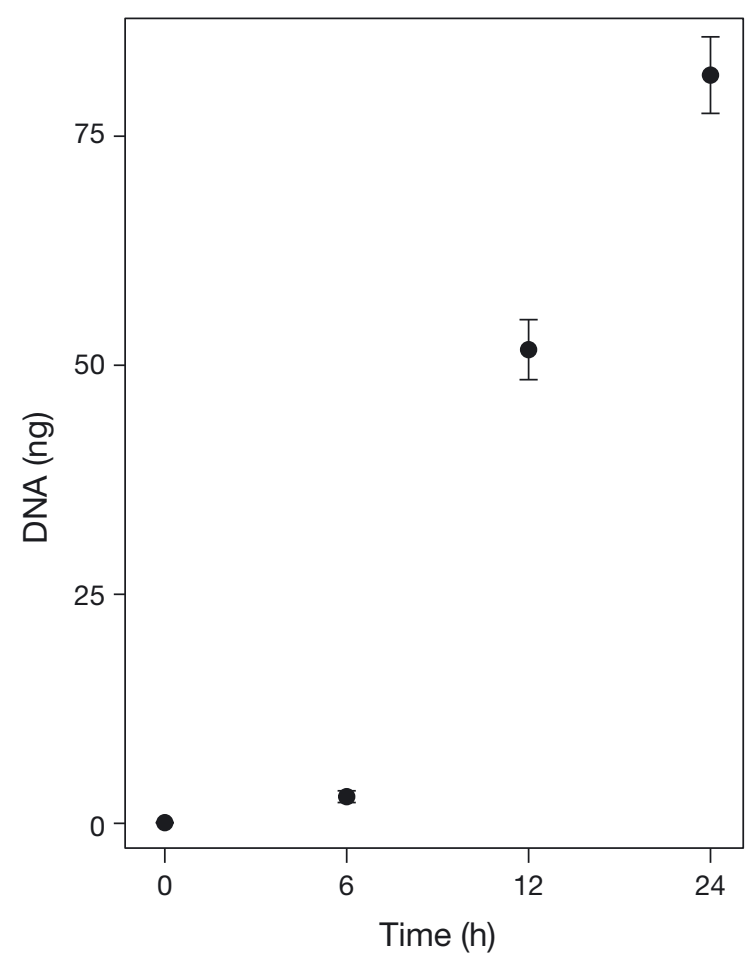

Fig. 2. Quantitative PCR results of bromodeoxyuridine (BrdU)-immunoprecipitated DNA from Paraphysomonas cultures fed BrdU-labeled bacteria, with primers specific to Paraphysomonas 18S rRNA sequence. Error bars represent $1 \mathrm{SE}$ of the mean

yielded 581 OTUs. Ten of these $(1.7 \%)$ were identified as chimeras and removed. After assigning taxonomy using the RDP database, we identified a total of 312 protist OTUs in the combined data set. Rarefaction curves from the pyrosequencing data showed that taxonomic sampling was more complete for the BrdU-IP samples than for the whole DNA samples at all depths (Fig. 3). This confirmed the expectation that the protists actively grazing bacteria represented a subset of the total microbial community. The majority of the OTUs recovered from each of the 'BrdU-IP' samples were also found in their respective 'whole DNA' samples (Fig. 4A), including all of the OTUs with high sequence abundance $(>0.1 \%$ of the total) from the BrdU-IP samples (Table 1). The rarefaction curves (Fig. 3) also predict that the ranking of diversity for both BrdU-IP and whole DNA samples will remain the same with deeper sequencing.

The greatest diversity was found in the metalimnion and least diversity in the hypolimnion (Figs. 3 \& 4A). Studies of protistan communities in a stratified anoxic fjord also found increased diversity at an intermediate depth within the pycnocline where density and chemistry was changing rapidly with 


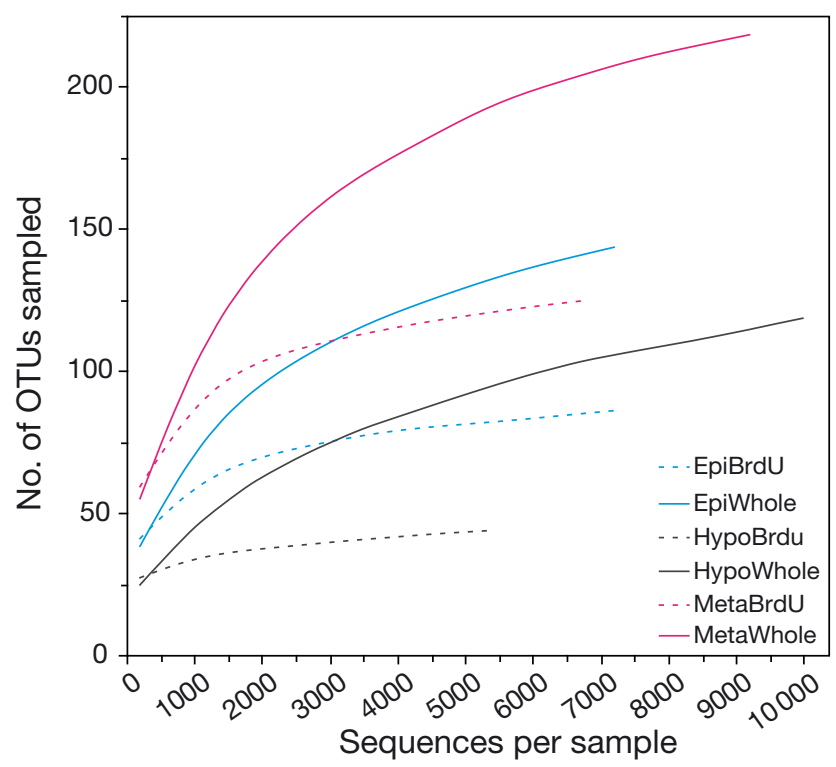

Fig. 3. Rarefaction curves of the 6 samples (mean of 20 values per step), showing the diversity of operational taxonomic units (OTUs). Data were sampled at 200 sequence increments up to $10^{4}$ sequences. EpiBrdU: epilimnion bromodeoxyuridine immunoprecipitated (BrdU-IP), EpiWhole: epilimnion whole DNA, HypoBrdU: hypolimnion BrdU-IP, HypoWhole: hypolimnion whole DNA, MetaBrdU: metalimnion BrdU-IP, MetaWhole: metalimnion whole DNA

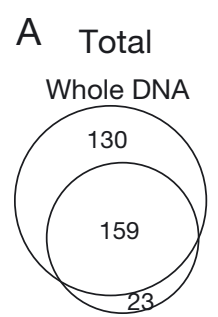

BrdU-IP

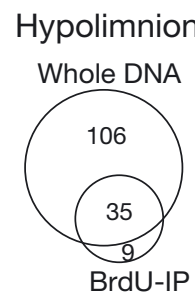

BrdU-IP

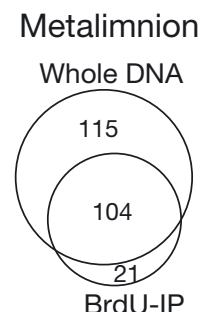

BrdU-IP
Epilimnion

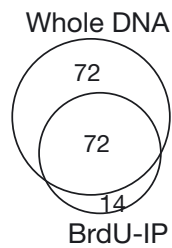

B

B Brdu-IP by depth

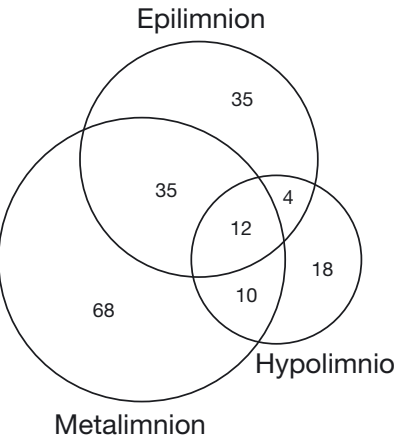

Whole DNA by depth Epilimnion

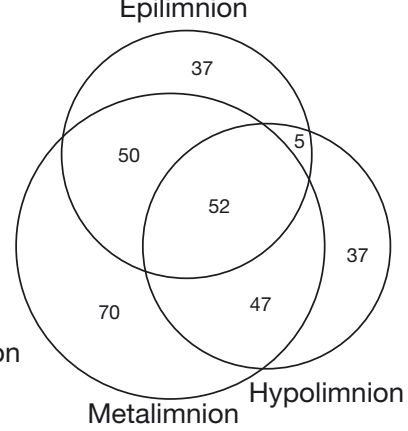

Fig. 4. Overlap in recovered operational taxonomic units (OTUs) between samples. (A) Comparison of OTUs identified from whole DNA samples and bromodeoxyuridine immunoprecipitated (BrdU-IP) samples for each depth sampled and for the combined lake community (total). (B) Overlap OTUs identified from all depths for BrdU and whole DNA samples depth (Behnke et al. 2006). The metalimnion is a layer of high biomass and fine-scale habitat differentiation, and is therefore expected to have high biodiversity (Finlay et al. 1997). Additionally, suspended organic macroaggregates that are numerically enriched in both heterotrophic and phototrophic protists are common in the metalimnion of this lake (Caron 1991) and offer a different habitat from the surrounding water. The epilimnion is a mixed surface layer, without the gradient of nutrients, temperature, and oxygen typical of the metalimnion, and thus may have reduced range of habitat type. Finding the lowest diversity in the hypolimnion was expected due to its more 'extreme' environmental conditions with low oxygen (Fig. 1) and higher hydrogen sulfide as evidenced by its distinct odor (S.A. Fay pers. obs.). Photosynthetic protists also would be more rare in the low light hypolimnion $\left(1.0 \mu \mathrm{mol} \mathrm{s}^{-1} \mathrm{~m}^{-2}\right)$. Despite the lower diversity in the hypolimnion, there was considerable overlap of OTUs identified from the layers in both BrdU-IP and whole DNA samples (Fig. 4 B) $;<7 \%$ and $<21 \%$ of the BrdU-IP and whole DNA OTUs, respectively, were unique to the hypolimnion. The proportion of OTUs shared between layers was always greater for the whole DNA than for BrdU-IP samples, regardless of which layers were compared (Fig. 4B). This likely reflects DNA from metabolically inactive cells or cysts that could sink through the water column that would have been identified in whole DNA samples, but not in samples labeled by feeding on BrdUlabeled bacteria.

\section{Community composition}

An analysis of community composition differentiating between the 6 samples using non-metric multidimensional scaling (NMDS) shows that the communities of eukaryotic microbes in the BrdU-IP samples are more similar to the communities of their respective whole DNA samples than they are to each other (Fig. 5). This pattern holds true using a variety of betadiversity distance metrics available in PRIMER 6, including ones that disregard relative abundances (Jaccard), incorporate joint absences (Euclidean), and incorporate phylogenetic signal (Unifrac, both weighted and unweighted for relative abundances). The relative sequence abundance of higher taxonomic categories among the samples (Fig. 6) is consistent with the NMDS analyses. The finding of different protist communities at different depths is not unique to Lake Lacawac and in fact is likely a widespread phenome- 


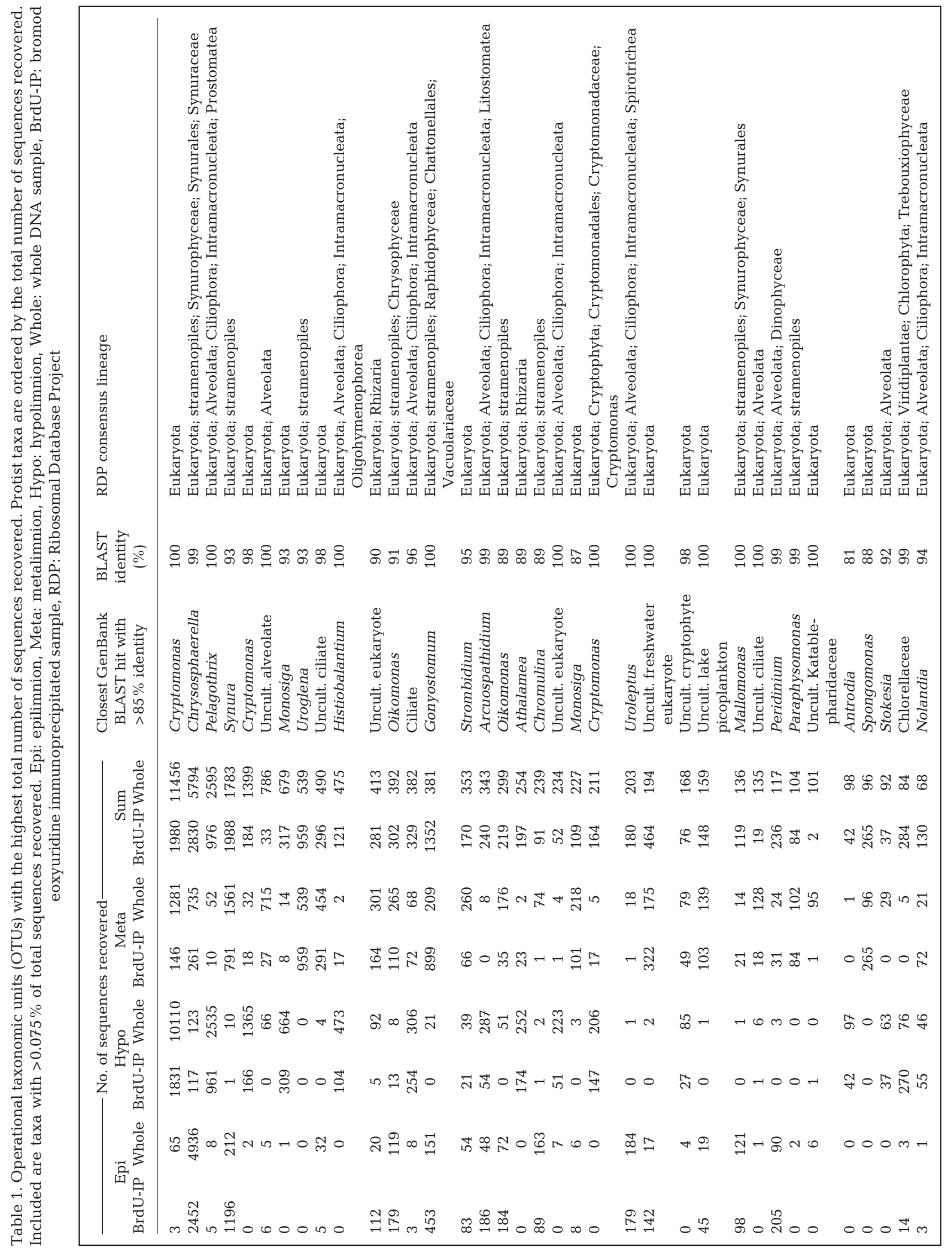


NMDS plot: Bray-Curtis similarity

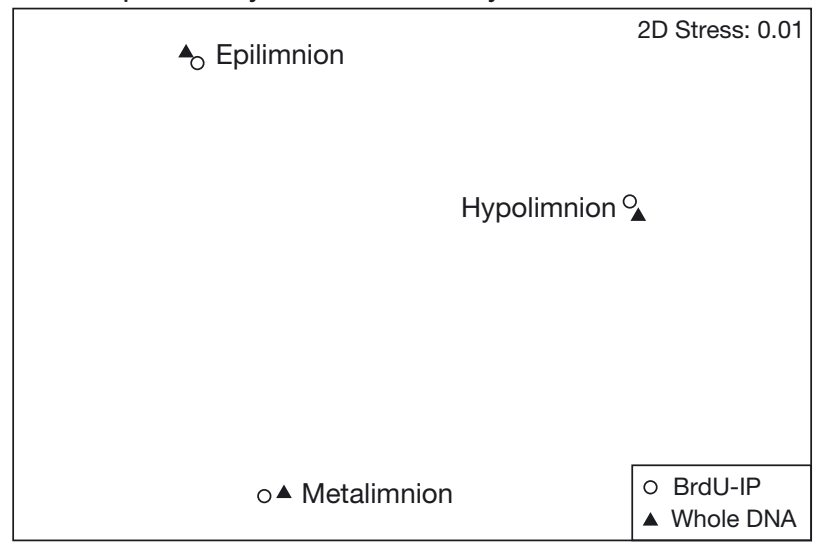

Fig. 5. Analysis of community similarity, showing non-metric multidimensional scaling (NMDS) 2D ordination of a BrayCurtis community dissimilarity matrix for the 6 samples. Close proximity of data points indicate high similarity

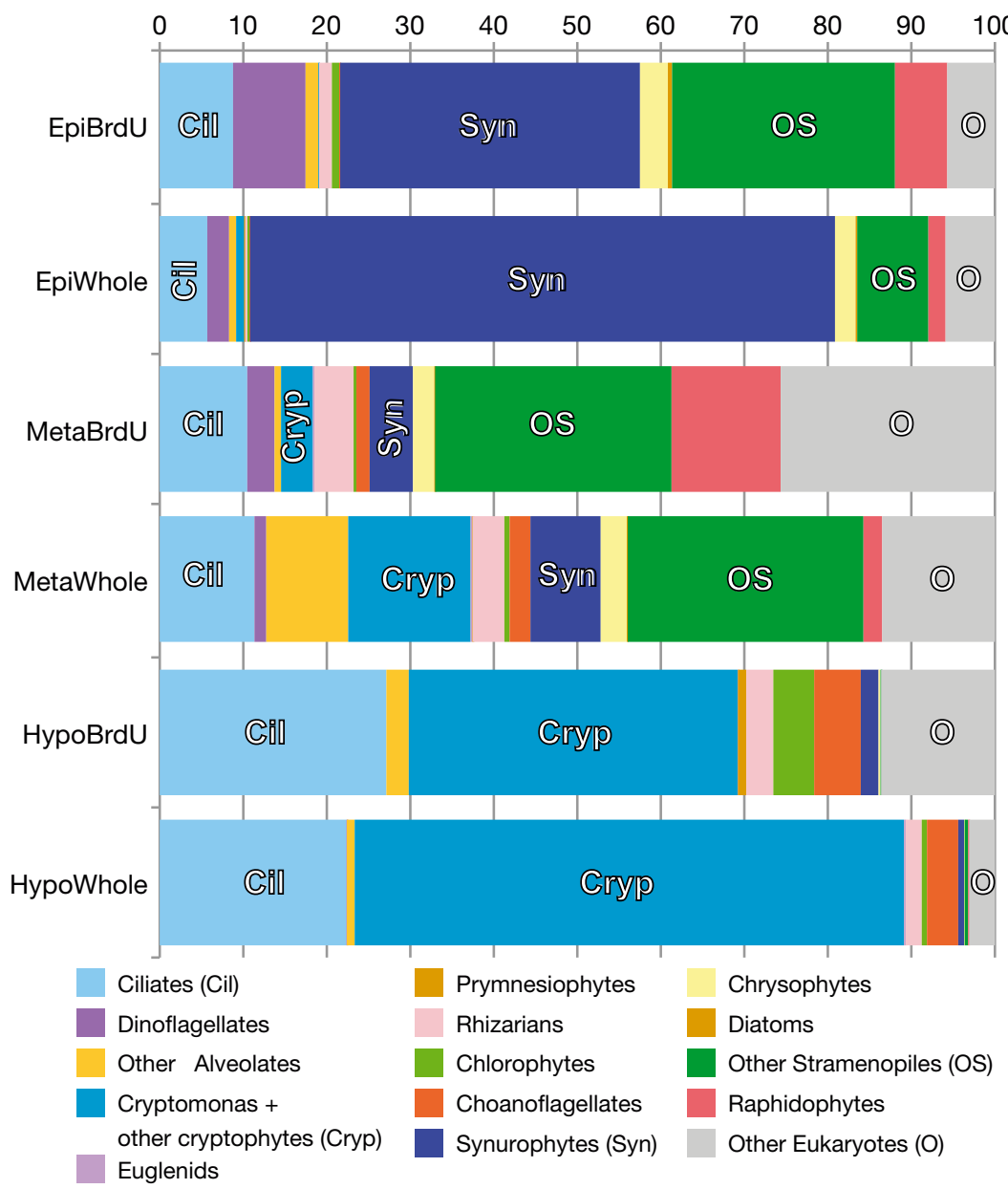

Fig. 6. Taxon plots, where bars show the relative abundance of sequences recovered from each higher-level taxon within each sample. EpiBrdU: epilimnion bromodeoxyuridine immunoprecipitated (brdU-IP), EpiWhole: epilimnion whole DNA, MetaBrdU: metalimnion BrdU-IP, MetaWhole: metalimnion whole DNA, HypoBrdU: hypolimnion BrdU-IP, HypoWhole: hypolimnion whole DNA non, having been noted in both shallow ponds and deep lakes (Finlay et al. 1988, Müller et al. 1991).

The most abundant OTUs from whole DNA (Table 1) and those with $>70 \%$ enrichment in the BrdU-IP samples (Table 2) come from a broad phyletic diversity of eukaryotes, including stramenopiles (particularly chrysophytes and synurophytes), alveolates (particularly ciliates and dinoflagellates), rhizarians, green algae, cryptophytes, and haptophytes. As indicated above, some groups showed especially large differences in their relative abundance at different depths (Fig. 6). Synurophytes, all of which have chloroplasts, are most common in the surface waters, while cryptomonads are more common in the hypolimnion (Fig. 6).

In Lake Lacawac, 9 of the 36 (25\%) most abundant OTUs in whole DNA samples and 13 of the $32(41 \%)$ most abundant OTUs in the BrdU-IP samples are most similar to uncultured organisms from environmental clone libraries or do not have any close homolog ( $\geq 85 \%$ sequence identity) in GenBank. This breadth of higher-level taxa from a single sample is known for several other planktonic systems, and a large proportion of the OTUs identified with molecular methods are often most similar to uncultured organisms (Luo et al. 2010). Note that close homologs to our sequences may have been recovered from other eukaryotic pyrosequencing projects, but tag sequences $<200 \mathrm{bp}$ unfortunately cannot be deposited in GenBank as per NCBI rules; unlike GenBank, the NCBI SRA can currently be searched only by project. Randa (2007) used a cloning procedure to identify bacterivores from 5 eukaryotic lineages (cercozoans, alveolates, stramenophiles, metazoans, and cryptophytes) that ingested BrdU-labeled bacteria in a coastal marine system. The majority of phylotypes labeled with BrdU in those experiments were also not closely related to previously identified protist species (Randa 2007).

\section{Recovery of poorly studied taxa}

There are apparently many bacterivores whose SSU rRNA genes have still never been studied. Compared to the whole DNA set of protistan taxa, a greater proportion of taxa labeled with 


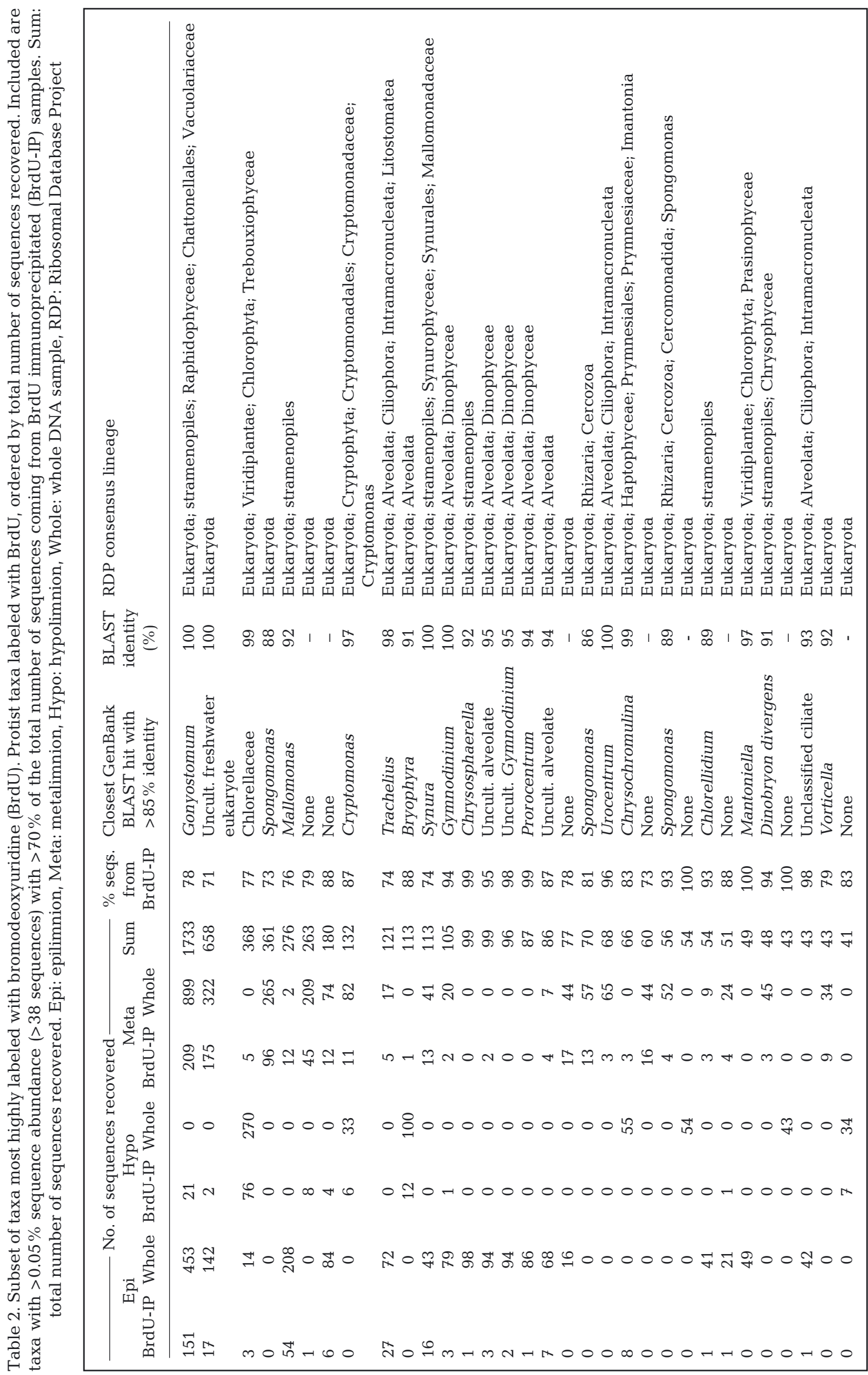


BrdU were poorly described or rare species. For 8 of the taxa in the list of BrdU-labeled taxa combined for all depths, we found no match to a GenBank sequence with $\geq 85 \%$ identity, whereas the 31 most commonly recovered taxa from the whole DNA samples all had some match within at least $85 \%$. These OTUs with no close homolog in GenBank are likely to be uncultured taxa. They may be more difficult to culture because they are fragile, small, difficult to distinguish as distinct taxa, or have specialized metabolic requirements. The relative proportion of unidentified OTUs found in the BrdU-labeled sequences suggests that BrdU is also useful for finding additional rare protist diversity.

\section{Identification of bacterivores}

We have taken a conservative approach to estimating those taxa that are truly BrdU-labeled and thus potentially bacterivorous. Factors such as non-linear PCR amplification and contamination from unlabeled taxa are possible, so only taxa with the highest proportion of BrdU-labeled versus whole DNA sequences recovered are listed in Table 1, i.e. taxa with $>0.05 \%$ sequence abundance and $>70 \%$ of the total number of sequences coming from BrdU-IP samples. We identify these taxa as putative bacterivores, either pure heterotrophs or mixotrophs. Confirmation of bacterivory as a trait may require continued experimental work in culture or field experiments. For example, the prasinophyte Mantoniella has not previously been reported as bacterivorous, but our results (Table 1), and the fact that our Antarctic Mantoniella isolate has been observed to ingest particles (McKie-Krisberg et al. 2011), suggest that more work should be done to examine bacterivory in this genus. Conversely, only a few diatom OTUs were recovered. A small proportion of the diatom sequences were in the BrdU-IP samples, and it is unlikely that these were bacterivorous. We see the approach taken in this paper as a hypothesisgenerating mode of research, analogous to transcriptomic assays (such as microarrays), which identify promising genes (or in this case particular taxa) for further study of function.

Among the most frequently identified BrdU-labeled protists, 3 of the 5 top hits were phytoplankton; an uncultured eukaryote and a heterotrophic flagellate rounded out the top 5 bacterivores (Table 1). The most sequences recovered in the BrdU-IP samples were for the raphidophyte Gonyostomum. Although mixotrophy, i.e. the combination of photosynthesis and feeding in an individual, has not been demonstrated for this genus, several species of marine raphidophytes were recently identified as mixotrophic (Jeong 2011). The 2 next most recovered algae were not previously identified as bacterivorous either, but known mixotrophic genera that were BrdU positive in these experiments included Cryptomonas, Chrysosphaerella, Chrysochromulina, Uroglena, and Dinobryon. These data highlight the potential importance of bacterivory as a mode of nutrition for many microalgae (Sanders 1991, Jones 2000, Zubkov \& Tarran 2008). It is possible that incubating the samples overnight enhanced phagotrophy in the mixotrophs, although darkness has no effect on some common mixotroph species (Bird \& Kalff 1987, Sanders et al. 2001).

Some of the BrdU-positive dinoflagellate genera identified as bacterivores contain both heterotrophic and mixotrophic species (Sanders \& Porter 1988). We do not identify these specifically as mixotrophs, although mixotrophy is well known for the group (Sanders 1991). Prasinophytes, previously identified as potentially bacterivorous by González et al. (1993), Bell \& Laybourn-Parry (2003), and Sanders \& Gast (2012), made up from $\sim 1$ to $5 \%$ and ciliates made up $\sim 8$ to $25 \%$ of the bacterivores from all 3 depths. Heterotrophic flagellates, including choanoflagellates, also were identified with BrdU at all depths (Fig. 6). A closer look at stramenopiles shows that, within this group, the 4 OTUs with the highest sequence abundance were Chrysosphaerella, Synura, Gonyostomum, and Uroglena. Over $60 \%$ of the sequences recovered for Uroglena were from BrdU-IP treatments, strongly supporting its ecological role as a bacterivore. Most stramenopile taxa found in this study fall within the chrysophyte/synurophyte group (their systematics remains in flux; Andersen 2007), and Fig. 6 emphasizes the fact that this taxonomically rich group of algae holds great opportunity for the comparative study of modes of nutrition.

Certain factors may confound the use of the BrdU method by identifying 'false positive' bacterivorous taxa. False positives may occur if osmotrophs take up free BrdU, and free BrdU may result from cycling of biomolecules. In axenic culture with $1 \mu \mathrm{M}$ BrdU, the phototrophs Nannochloris atomus, Gymnodidinium sanguineum, and Phaeodactylum tricornutum did not incorporate BrdU directly from the medium, but the osmotrophic labyrinthulomycete Schizochytrium aggregatum did become labeled (Randa 2007). Even green plants can take up free DNA (Paungfoo-Lonhienne et al. 2010). Although bacteria are better competitors for the dissolved DNA than protists (Løvdal et al. 2007) and likely for BrdU as well, we recommend low centrifugation speeds, gentle methods for 
dispersion of cells, and minimization of the time between washing/centrifugation of BrdU-labeled bacteria and their addition to environmental samples to minimize potential leakage of free BrdU or freeBrdU-labeled-DNA.

Non-protistan bacterivores can also be identified by this method. Though not recorded in the tables of most commonly recovered sequences, rotifers and copepods were appropriately identified as bacterivorous in the analysis. Predators of bacterivorous protists (including other protists) at higher trophic levels might also become labeled, again generating false positives. Since this requires time for ingestion of the labeled bacterivore followed by growth and incorporation into the secondary predator's DNA, minimizing incubation times is one way to ameliorate this problem.

An important assumption in this work is that bacterivores would not be identified if they did not incorporate BrdU into their DNA after ingestion. While not all bacteria take up thymidine or BrdU, little is known about incorporation of complete nucleotides by protists. Caron et al. (1993) found that ${ }^{3} \mathrm{H}$-thymidine from labeled bacteria did accumulate in protists, but not quantitatively over periods longer than several hours; this implies that some of the nucleotide is broken down. However, Taylor \& Sullivan (1984) found that when bacteria were labeled with ${ }^{14} \mathrm{C}$-thymidine and fed to the ciliate Euplotes, respiration and exudation were less than in experiments using ${ }^{14} \mathrm{C}$-glucose, implying that a consumer is more likely to use nucleotides in anabolic processes. Protists that failed to ingest the labeled bacteria for any reason, and those with very low feeding rates, could also lead to false negatives. Size-selective feeding by protists is well known (González et al. 1990), but this is most likely to be a problem if a strain of large bacteria is used and the grazers are very small (Sanders \& Gast 2012). Future work with BrdU could be directed towards labeling the natural bacterial community to reduce the effect of prey size or type, although as noted previously, not all bacteria take up BrdU or thymidine. The data presented here and by Randa (2007) show that many protists incorporate ingested nucleotides directly into their DNA, and that this method can be utilized to gain an important perspective into the link between taxonomic diversity and function.

\section{CONCLUSION}

The large phylogenetic diversity of eukaryotic microorganisms is well recognized and ascribed to a large extent to uncultured species (Medinger et al. 2010). Consequently, the ability to assign functional importance to various groups in an aquatic food web is still limited. Culture-independent molecular methods, including the BrdU-IP method used here, can partition microbial taxa by function. Most other culture-independent studies involve stable isotope probing (SIP, reviewed by Gutierrez-Zamora \& Manefield 2010), whereby microbes are fed with heavy stable isotope labeled substrates. Like any technique, SIP has its drawbacks. It can be difficult to achieve sufficient incorporation of the heavy isotope, especially with in situ levels of the substrate (Chen \& Murrell 2010). Additionally, centrifugal separation of labeled nucleic acids is not complete, and background levels of template are present in all fractions (Lueders et al. 2004).

One advantage of using halogenated nucleotides like BrdU for labeling and separation by IP is that monoclonal antibodies have very high binding affinity and will bind regardless of the molecular weight of the antigen. Our study demonstrates the utility of combining BrdU-labeling and next-generation amplicon sequencing to study microbial trophic ecology. These data show that bacterivores from a small set of lakewater samples are distributed widely across the eukaryotic tree of life. Furthermore, many of the protists identified as bacterivores are algae. The occurrence of mixotrophic algae in pelagic ecosystem nutrient flux is now well established (Sanders \& Porter 1988, Jeong et al. 2010). Culture-independent methods such as BrdU-labeling add to the toolbox available for studying natural protist communities, and models of aquatic microbial food webs must continue to incorporate and expand on knowledge of the functional diversity of the many unculturable protists, including mixotrophs.

Acknowledgements. We thank the Lake Lacawac Foundation for maintaining access to the lake for research, M. Randa and E. Lim for their advice on and discussion of the BrdU method, which they first developed, I. Akan for advice on immunochemistry, and S. DeVaul for assistance in the laboratory. This work was funded in part by NSF grants OPP-0838847 and OPP-0838955. The funding agency had no role in study design, data collection and analysis, decision to publish, or preparation of the manuscript.

\section{LITERATURE CITED}

Amaral-Zettler LA, McCliment EA, Ducklow HW, Huse SM (2009) A method for studying protistan diversity using massively parallel sequencing of V9 hypervariable regions of small-subunit ribosomal RNA genes. PLoS ONE 4:e6372 
Andersen RA (2007) Molecular systematics of the Chrysophyceae and Synurophyceae. In: Brodie J, Lewis J (eds) Unravelling the algae: the past, present, and future of algal systematics. CRC Press, Boca Raton, FL, p 285-315

$>$ Azam F, Fenchel T, Field JG, Gray JS, Meyer-Reil LA, Thingstad F (1983) The ecological role of water-column microbes in the sea. Mar Ecol Prog Ser 10:257-263

$>$ Behnke A, Bunge J, Barger K, Breiner HW, Alla V, Stoeck T (2006) Microeukaryote community patterns along an $\mathrm{O}_{2} / \mathrm{H}_{2} \mathrm{~S}$ gradient in a supersulfidic anoxic fjord (Framvaren, Norway). Appl Environ Microbiol 72:3626-3636

Behnke A, Engel M, Christen R, Nebel M, Klein RR, Stoeck $\mathrm{T}$ (2011) Depicting more accurate pictures of protistan community complexity using pyrosequencing of hypervariable SSU rRNA gene regions. Environ Microbiol 13: 340-349

Bell EM, Laybourn-Parry J (2003) Mixotrophy in the Antarctic phytoflagellate, Pyramimonas gelidicola (Chlorophyta: Prasinophyceae). J Phycol 39:644-649

> Berninger U, Caron DA, Sanders RW (1992) Mixotrophic algae in three ice covered lakes of the Pocono Mountains, U.S.A. Freshw Biol 28:263-272

- Bik HM, Porasinska DL, Creer S, Caporaso JG, Knight R, Thomas WK (2012) Sequencing our way towards understanding global eukaryotic biodiversity. Trends Ecol Evol 27:233-243

> Bird DF, Kalff J (1987) Algal phagotrophy: regulating factors and importance relative to photosynthesis in Dinobryon (Chrysophyceae). Limnol Oceanogr 32:277-284

Caporaso JG, Kuczynski J, Stombaugh J, Bittinger K and others (2010) QIIME allows analysis of high-throughput community sequencing data. Nat Methods 7:335-336

Caron DA (1991) Heterotrophic flagellates associated with sedimenting detritus. In: Patterson DJ, Larsen J (eds) The biology of free-living heterotrophic flagellates. Clarendon Press, Oxford, p 77-92

Caron DA, Lessard EJ, Voytek M, Dennett MR (1993) Use of tritiated thymidine (TdR) to estimate rates of bacterivory: implications of label retention and release by bacterivores. Mar Microb Food Webs 7:177-196

- Chen Y, Murrell JC (2010) When metagenomics meets stable-isotope probing: progress and perspectives. Trends Microbiol 18:157-163

Clarke K, Warwick R (2001) Change in marine communities: an approach to statistical analysis and interpretation, 2nd edn. PRIMER-E, Plymouth

Edgar RC (2010) Search and clustering orders of magnitude faster than BLAST. Bioinformatics 26:2460-2461

Finlay BJ, Clarke KJ, Cowling AJ, Hindle RM, Rogerson A, Berninger UG (1988) On the abundance and distribution of protozoa and their food in a productive freshwater pond. Eur J Protistol 23:205-217

Finlay BJ, Maberly SC, Cooper JI (1997) Microbial diversity and ecosystem function. Oikos 80:209-213

Gast RJ, Dennett MR, Caron DA (2004) Characterization of protistan assemblages in the Ross Sea, Antarctica, by denaturing gradient gel electrophoresis. Appl Environ Microbiol 70:2028-2037

González JM, Sherr EB, Sherr BF (1990) Size-selective grazing on bacteria by natural assemblages of estuarine flagellates and ciliates. Appl Environ Microbiol 56:583-589

González JM, Sherr EB, Sherr BF (1993) Digestive enzyme activity as a quantitative measure of protistan grazing: the acid lysozyme assay for bacterivory. Mar Ecol Prog Ser 100:197-206
Gutierrez-Zamora ML, Manefield M (2010) An appraisal of methods for linking environmental processes to specific microbial taxa. Crit Rev Environ Sci Technol 9:153-185

Hamasaki K, Taniguchi A, Tada Y, Long RA, Azam F (2007) Actively growing bacteria in the inland Sea of Japan, identified by combined bromodeoxyuridine immunocapture and denaturing gradient gel electrophoresis. Appl Environ Microbiol 73:2787-2798

Jeong HJ (2011) Mixotrophy in red tide algae raphidophytes. J Eukaryot Microbiol 58:215-222

Jeong HJ, Yoo YD, Kim JS, Seong KA, Kang NS, Kim TH (2010) Growth, feeding and ecological roles of the mixotrophic and heterotrophic dinoflagellates in marine planktonic food webs. Ocean Sci J 45:65-91

> Jones RI (2000) Mixotrophy in planktonic protists: an overview. Freshw Biol 45:219-226

Kemp PF, Sherr BF, Sherr EB, Cole JJ (eds) (1993) Handbook of methods in aquatic microbial ecology. CRC Press, Boca Raton, FL

Kuske CR, Banton KL, Adorada DL, Stark PC, Hill KK, Jackson PJ (1998) Small-scale DNA sample preparation method for field PCR detection of microbial cells and spores in soil. Appl Environ Microbiol 64:2463-2472

454 Life Sciences Corp. (2010) GS Junior System guidelines for amplicon experimental design. 454 Life Sciences, Branford, CT

> Løvdal T, Tanaka T, Thingstad TF (2007) Algal-bacterial competition for phosphorus from dissolved DNA, ATP, and orthophosphate in a mesocosm experiment. Limnol Oceanogr 52:1407-1419

Lozupone CA, Hamady M, Kelley ST, Knight R (2007) Quantitative and qualitative beta diversity measures lead to different insights into factors that structure microbial communities. Appl Environ Microbiol 73:1576-1585

$>$ Lueders T, Manefield M, Friedrich MW (2004) Enhanced sensitivity of DNA and rRNA based stable isotope probing by fractionation and quantitative analysis of isopycnic centrifugation gradients. Environ Microbiol 6:73-78

Luo W, Bock C, Li HR, Padisák J, Krienitz L (2010) Molecular and microscopic diversity of planktonic eukaryotes in the oligotrophic Lake Stechlin (Germany). Hydrobiologia 661:133-143

- Macaluso AL, Mitchell DL, Sanders RW (2009) Direct effects of UV-B radiation on the freshwater heterotrophic nanoflagellate Paraphysomonas sp. Appl Environ Microbiol 75:4525-4530

McKie-Krisberg Z, Fay SA, Sanders RW (2011) Competitive assays of two mixotrophs and two diatoms from the Ross Sea, Antarctica. J Phycol 47:S67

- Medinger R, Nolte V, Pandey RV, Jost S, Ottenwälder B, Schlötterer C, Boenigk J (2010) Diversity in a hidden world: potential and limitation of next generation sequencing for surveys of molecular diversity of eukaryotic microorganisms. Mol Ecol 19:32-40

> Müller H, Schöne A, Pinto-Coelho RM, Schweizer A, Weisse $\mathrm{T}$ (1991) Seasonal succession of ciliates in Lake Constance. Microb Ecol 21:119-138

> Newman DK, Banfield JF (2002) Geomicrobiology: how molecular-scale interactions underpin biogeochemical systems. Science 296:1071-1077

> Olsen GJ, Lane DJ, Giovannoni SJ, Pace NR, Stahl DA (1986) Microbial ecology and evolution: a ribosomal RNA approach. Annu Rev Microbiol 40:337-365

Paul EA (2007) Soil microbiology, ecology, and biochemistry, 3rd edn. Academic Press, Boston, MA 
Paungfoo-Lonhienne C, Lonhienne TGA, Mudge SR, Schenk PM, Christie M, Carroll BJ, Schmidt S (2010) DNA is taken up by root hairs and pollen, and stimulates root and pollen tube growth. Plant Physiol 153: 799-805

Randa MA (2007) The role of temperature, salinity, and protozoan predation on the population dynamics of Vibrio vulnificus in Barnegat Bay, New Jersey. PhD dissertation, Temple University, Philadelphia, PA

Reeder J, Knight R (2010) Rapidly denoising pyrosequencing amplicon reads by exploiting rank-abundance distributions. Nat Methods 7:668-669

Rozen S, Skaletsky H (2000) Primer3 on the WWW for general users and for biologist programmers. Methods Mol Biol 132:365-386

Sanders RW (1991) Mixotrophic protists in marine and freshwater ecosystems. J Eukaryot Microbiol 38:76-81

Sanders RW, Gast RJ (2012) Bacterivory by phototrophic picoplankton and nanoplankton in Arctic waters. FEMS Microbiol Ecol 82:242-253

Sanders RW, Porter KG (1988) Phagotrophic phytoflagellates. In: Marshall KC (ed) Advances in microbial ecology. Plenum, New York, NY, p 167-192

Sanders RW, Caron DA, Davidson JM, Dennett MR, Moran DM (2001) Nutrient acquisition and population growth of a mixotrophic alga in axenic and bacterized cultures. Microb Ecol 42:513-523

Sherr EB, Sherr BF (2002) Significance of predation by pro-

Editorial responsibility: Klaus Jürgens,

Rostock, Germany tists in aquatic microbial food webs. Antonie Leeuwenhoek 81:293-308

Siver PA, Chock JS (1986) Phytoplankton dynamics in a chrysophycean lake. In: Kristiansen J, Andersen RA (eds) Chrysophytes: aspects and problems. Cambridge University Press, Cambridge, p 165-183

Sogin ML, Morrison HG, Huber JA, Welch DM and others (2006) Microbial diversity in the deep sea and the underexplored 'rare biosphere'. Proc Natl Acad Sci USA 103: 12115-12120

Stoeck T, Bass D, Nebel M, Christen R, Jones MDM, Breiner H, Richards TA (2010) Multiple marker parallel tag environmental DNA sequencing reveals a highly complex eukaryotic community in marine anoxic water. Mol Ecol 19:21-31

Taylor GT, Sullivan CW (1984) The use of ${ }^{14} \mathrm{C}$-labeled bacteria as a tracer of ingestion and metabolism of bacterial biomass by microbial grazers. J Microbiol Methods 3: 101-124

> Ueda J, Saito H, Watanabe H, Evers BM (2005) Novel and quantitative DNA dot-blotting method for assessment of in vivo proliferation. Am J Physiol 288:G842-G847

> Urbach E, Vergin KL, Giovannoni SJ (1999) Immunochemical detection and isolation of DNA from metabolically active bacteria. Appl Environ Microbiol 65:1207-1213

Zubkov MV, Tarran GA (2008) High bacterivory by the smallest phytoplankton in the North Atlantic Ocean. Nature 455:224-226

Submitted: March 26, 2013; Accepted: October 14, 2013 Proofs received from author(s): November 25, 2013 